\title{
Mass-balance studies on Siachen Glacier in the Nubra valley, Karakoram Himalaya, India
}

\author{
M. R. Bhutiyani \\ College of Military Engineering, Pune 411 031, India
}

\begin{abstract}
The hydrological method is used to compute the mass balance of Siachen Glacier in the Nubra Valley, Karakoram Himalaya, India. The method was chosen because of its suitability in rugged terrain. Analysis of precipitation data from the glacier as a function of altitude shows a power-law relationship. Accumulation estimates based on this relationship show good agreement with the recorded precipitation. The discharge data from the glacier show high runoff in the ablation seasons of 1986-87, 1987-88, 1989-90 and 1990-91. The mass-balance calculations for these years are negative, the lowest being in 1990-91 (-1084 mm). Positive mass balance in $1988-89(+358 \mathrm{~mm})$ is attributed to comparatively heavy winter snowfall amounts and comparatively low temperatures during the ablation season. Significantly lower runoff was measured during this season. Negative mass-balance values during 1989-90 and 1990-91 are a result of comparatively dry winters and comparatively warm ablation periods, with monthly mean air temperatures $1.4-5.1^{\circ} \mathrm{C}$ higher at the beginning of the ablation season (June and July) than the mean of the last 5 years.
\end{abstract}

\section{INTRODUCTION}

The Himalayan mountain range exerts a dominant control over hydrological and meteorological conditions in the Indian peninsula. Most of the rivers on the Indo-Gangetic plains derive their runoff from seasonal snowmelt and/or glacier melt. The hydrology of these rivers is strongly influenced by the behaviour of glaciers, which act as natural regulators of water by storing it in winter as snow and releasing it in summer in the form of meltwater (Vohra, 1981). In order to manage the water resources of these rivers judiciously, a proper understanding of the mass balance of the glaciers and their hydrological characteristics is important.

The mass balance of valley glaciers can be studied by various methods, including the stratigraphic or glaciological method, the geodetic method and the hydrological method (Ostrem and Stanley, 1969; Meier, 1973). In the stratigraphic or glaciological method, the mass balance is determined directly from measurements of accumulation and ablation of mass at the glacier surface by taking point measurements (Röthlisberger and Lang, 1987). The geodetic method is based on repeated photogrammetric or theodolite surveys of a glacier over a period of 5-10 years. The hydrological method determines the mass balance by subtracting the mass losses by evaporation and runoff from the mass gain from snowfall.

Unlike other methods, the hydrological method relies on indirect estimates of annual accumulation and ablation from snow-meteorological and discharge data. Massbalance estimates using this method over short time periods (e.g. weekly or daily) have been extremely unreliable due, apparently, to the storage of liquid water within the glacier in its subglacial and englacial cavities, or the release of this liquid water (Tangborn and others, 1975). It is observed that these cavities begin to open in mid-May and reach a maxi- mum total volume by August, at which time they contain the maximum water volume. By the end of the ablation season (end of September), much of the water stored in these cavities is drained off (Östling and Hooke, 1986). This variation often leads to significant errors in estimation of mass loss calculated by the hydrological method as compared to the loss for the same area measured by the glaciological method for short time periods. However, comparison of mass balance calculated by the glaciological and hydrological methods on South Cascade Glacier, Washington, U.S.A., for a longer duration of 3-7 years has generally shown that results from the hydrological method are within acceptable error limits (Tangborn and others, 1975). Therefore, it can be assumed that changes in liquid-water storage within the glacier over short time periods, i.e. daily or weekly, are significant and cannot be ignored in estimation of mass loss, but over longer duration (annually or longer) they are insignificant and hence can be ignored.

Large expanses of the Karakoram Himalaya, and the Nubra valley in particular, are inaccessible throughout the year due to the extremely rugged and difficult nature of the terrain. Because of the dangers involved in working on them, most of the glaciers have been only partially explored. A few studies on geomorphological aspects Goudie and others, 1984) and the relationship between discharge variation and sediment transport in the Hunza Glacier basin (Ferguson, 1984) have been reported in the literature, but no mass-balance data are available on any of the glaciers. Considerable manpower and logistic support is required to study the glaciers using stratigraphic and geodetic methods. These methods, however accurate, are suitable only for small glaciers, where periodic monitoring of accumulation and ablation measurements at different stakes is physically possible. Because of their huge size, the glaciers in the Karakoram Himalaya can only be studied for longer periods by 
the hydrological method, although results may be less accurate than those obtained by other methods.

This paper, the first study of its kind in this part of the Himalaya, presents the results of mass-balance studies carried out on Siachen Glacier during the five hydrological years $1986-87$ to $1990-91$.

\section{THE STUDY AREA}

The Karakoram Himalaya is highly glacierized (about $37 \%$ glacier area) and is characterized by steep slopes and an altitude range of $2800-7600 \mathrm{~m}$. The Shyok river, with the Nubra river as a tributary, is a major river system in the area (Fig. 1). The northwest-southeast trending Siachen Glacier, the longest of the 33 glaciers in the Nubra valley, is a compound glacier about $74 \mathrm{~km}$ long. It is the source of the Nubra river.

Precipitation in the Karakoram Himalaya occurs under the influence of extratropical low-pressure systems called Western Disturbances (WDs) (Rangachary and Bandyopadhyay, 1987). Studies have shown that the higher altitudes of the area receive snowfall year-round, while the lower altitudes receive $95 \%$ of their total precipitation as snow and the other $5 \%$ as rain. About $40-50$ WDs move over the Karakoram Himalaya every year, with an average frequency of four to five per month and a life expectancy of 2 4 days for each WD (Bhutiyani, 1992). The lower altitudes receive about $75-150 \mathrm{~cm} \mathrm{a}^{-1}$ of snowfall (snow depth), while higher altitudes can receive $>1000 \mathrm{~cm} \mathrm{a}^{-1}$. The snow exhibits dry, powdery characteristics with a predominance of columns, needles and dendrites as snow-crystal types. Formation of depth-hoar crystals in the snowpack is fairly
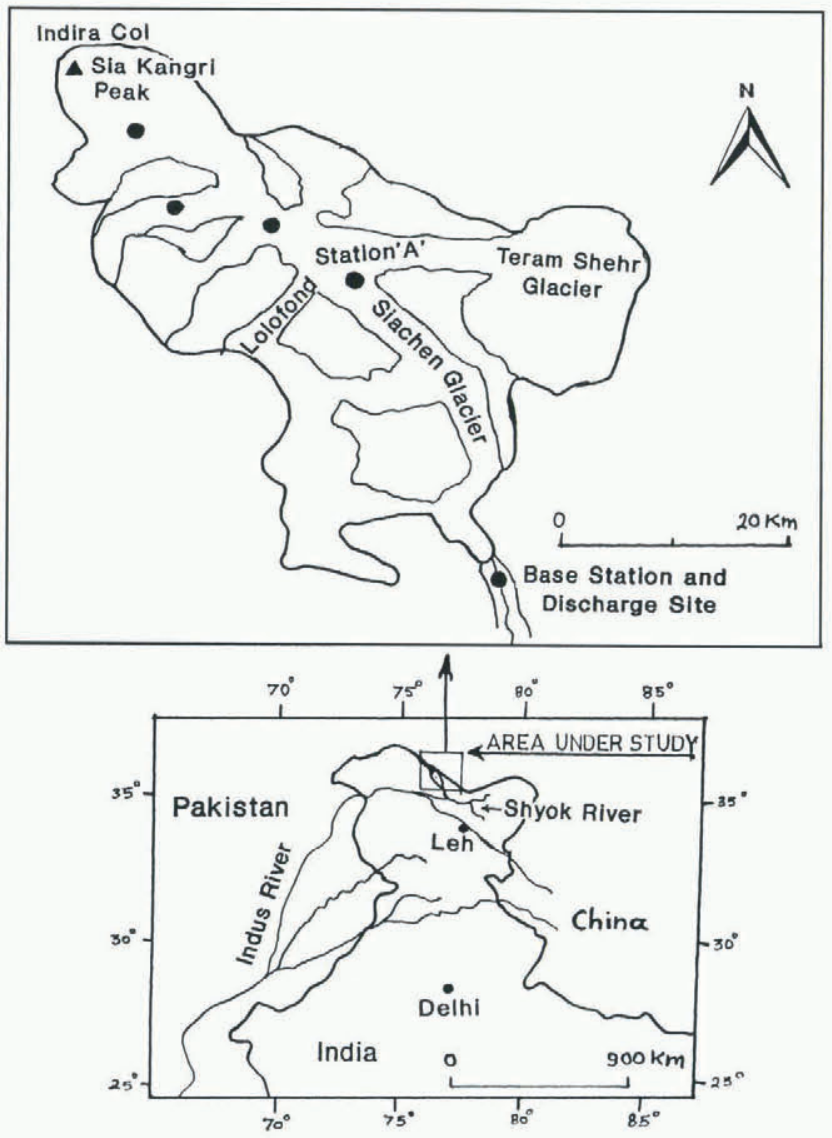

Fig. 1. Location map. common. Minimum air temperatures ranging from $-20^{\circ}$ to $-40^{\circ} \mathrm{C}$ have been recorded in December-February.

A network of five manned snow-meteorological observatories (four on the glacier and one at the base station) was set up primarily for the purpose of avalanche forecasting at the locations shown in Figure 1. Snowfall amounts (in $\mathrm{cm}$ snow depth) were measured manually using standard snow stakes, and maximum, minimum and ambient air-temperature data were collected using standard thermometers. These data were recorded twice a day at 0830 and $1730 \mathrm{~h}$ (Indian Standard Time). Fresh snowfall density was measured at station $\mathrm{A}$ and at the base station. Assuming that station $\mathrm{A}$ is representative of the whole glacier basin (because of its geographical location in the central part of the basin), its freshsnow density and air-temperature data were used to convert fresh-snow depths at other stations on the glacier into water equivalents and compute evaporation losses.

Discharge measurements were taken $200 \mathrm{~m}$ downstream of the glacier snout where the river has a more-or-less uniform cross-sectional area and negligible gradient for about $50 \mathrm{~m}$. A vertical gauge was installed and calibrated by measuring discharge using the area-velocity method. Surface velocities at three places across the river channel were measured using light, wooden floats and their average was taken. Mean flow velocity was calculated using a conversion constant of 0.85 (Ostrem, 1964). Cross-sectional area was monitored twice a year and corrections were applied to the rating curve. The salt-dilution method (Ostrem, 1964) was also tried, but did not give the desired results because of high discharge and some practical problems.

\section{MASS BALANCE BY HYDROLOGICAL METHOD: DISGUSSION OF RESULTS}

\section{Net accumulation}

\section{Variation of precipitation with altitude}

Estimation of precipitation in a mountainous basin is one of the greatest problems in mountain hydrology, because significant spatial and altitudinal variations are common. Orography is important in the distribution of snowfall in the Himalaya. Studies in the Nepal Himalaya (Higuchi and others, 1982), in the Pirpanjal Himalaya (Bagchi, 1982) and in the Greater Himalaya (Singh, 1994) have indicated that snowfall increases with altitude on the windward side (southern slopes) up to a certain altitude and then decreases on the leeward side. Analysis of the precipitation data collected at the five stations located at different altitudes on Siachen Glacier (Fig. 2) shows that the lower elevations in the valley generally received low annual snowfall of 75 $150 \mathrm{~cm}$ snow depth, while the higher elevations received moderate to heavy snowfall ranging up to $1000 \mathrm{~cm}$ snow depth. Analysis (Fig. 2) suggests a power-law relation between precipitation and altitude in the Siachen Glacier valley, which is on the windward side of the Karakoram Himalaya. Using this relationship the precipitation at any desired location on the glacier is given by an expression:

$$
P_{\mathrm{b}}=P_{\mathrm{r}}\left(A_{\mathrm{b}} / A_{\mathrm{r}}\right)^{C}
$$

where $P_{\mathrm{b}}$ is precipitation at any desired location on the glacier, $P_{\mathrm{r}}$ is precipitation measured at a known station, $A_{\mathrm{b}}$ is altitude of the desired location where precipitation is to be estimated, $A_{\mathrm{r}}$ is altitude of a known station where precipita- 


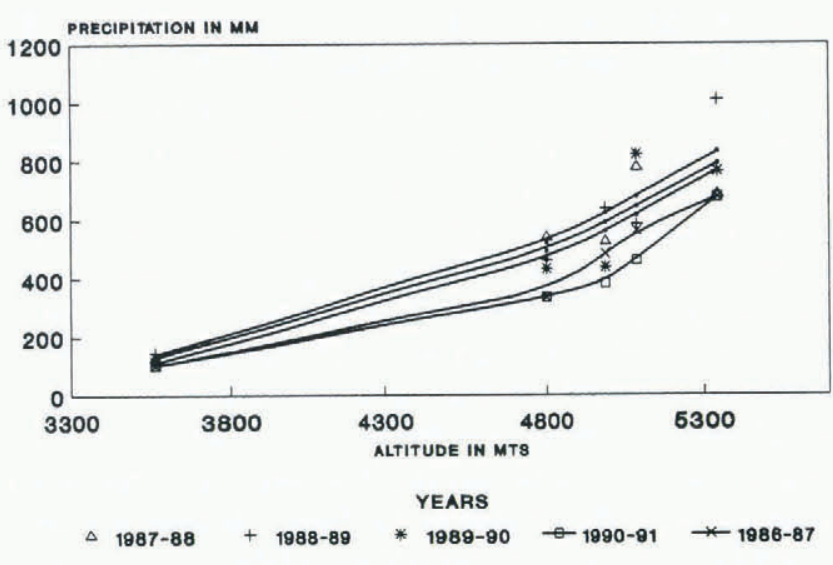

Fig. 2. Variation of precipitation with altitude in the Nubra valley.

tion measurements are taken, and $C$ is altitude factor with a value of 4.78 .

A good correlation $\left(R^{2}=0.89\right)$ is obtained during the study period (Fig. 3). The relationship does not take into consideration the local variation in deposition caused by the wind transport over different slope angles and aspects.

\section{Accumulation}

To estimate the total accumulation over the glacier surface, the entire glacier basin was divided into six altitude zones, each with an altitude interval of $500 \mathrm{~m}$ (Fig. $4 \mathrm{a}$ and b). The area within each zone was planimetered on the map, and the mean altitude calculated (Table 1). Zones 1-4 and part of zone 5 were observed to be in the ablation area, and zone 6 with part of zone 5 in the accumulation area. No precise data on year-to-year variation of equilibrium-line altitude (ELA) are available for the study period. The field visits undertaken during ablation periods in different years have indicated ELAs of 5400-5600 $\mathrm{m}$ during the study period. This shows that $>50 \%$ of the glacier area lies below the equilibrium line. Siachen Glacier is a rapidly retreating, debris-covered glacier which retreated by about $914 \mathrm{~m}$ during the period 1929-58 (Vohra, 1981). The generalized accumulation area ratio $(\mathrm{AAR})$ for the glaciers in this region has a value of 0.44 for zero mass balance (Kulkarni, 1992).

Except for station $\mathrm{A}$ and one other station at an altitude of $5300 \mathrm{~m}$, none of the stations was located near the mean altitudes of the corresponding zones. To make a representative assessment of precipitation estimates at mean hypsometric altitudes of different zones and to create uniformity in the calculation for each zone, base-station data were used because of the availability of a continuous year-round record for all years during the study period, and the minimal effect of wind-drift on precipitation measurements. Using the relationship given in Equation (1), total annual precipitation at different elevations during the five hydrological years $1986-87$ to $1990-91$ were computed by taking the total annual precipitation recorded in respective years at the base station ( $3570 \mathrm{~m}$ a.s.1.).

The contribution to the accumulation due to avalanches from non-glacierized areas in the basin was observed to be significant in all zones except 1 and 6 . The non-glacierized parts of the basin consist mainly of steep slopes (angles $>50^{\circ}$ ) with smooth and rocky or scree-filled sliding surfaces. Most of the accumulation on these slopes is brought down to the glacier by the many dry, loose snow avalanches that occur immediately after every major snowfall event
Estimated precipitation in $\mathrm{mm}$

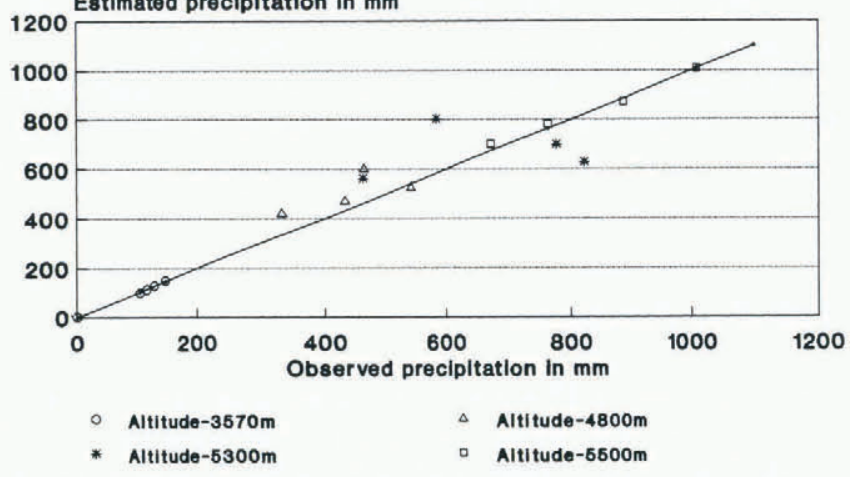

Fig. 3. Relationship between observed and estimated values of precipitation at different altitudes.

(Bhutiyani, 1992). The precipitation in the catchment areas of the avalanche zones is calculated by applying the elevation-precipitation regression equation (Equation (1)). An average depth of snow retained on such slopes after an avalanche occurrence is taken as $0.15 \mathrm{~m}$ (Schaerer, 1975). Assuming that all non-glacierized areas in zones $2-5$ are catchment areas for avalanches, their contribution, weighted by their areas (in relation to the glacier areas of corresponding zones), is calculated after subtracting a residual of $0.15 \mathrm{~m}$ and this amount was added to accumulation estimates of corresponding zones. In glacierized areas, an altitude interval of $500 \mathrm{~m}$ was chosen so as to include the entire avalanche paths of these sites and their contribution to accumulation within the same altitude zone. Table 2 gives the details of estimated total annual precipitation at mean hypsometric altitudes of all altitude zones.

The mean specific accumulation on the glacier surface during a particular year was computed by taking a weighted mean of total annual precipitation estimated at various altitudes by using the expression:

$$
S_{\mathrm{a}}=\frac{\sum P_{i} A_{i}}{\sum A_{i}}
$$

where, $S_{\mathrm{a}}$ is mean specific accumulation in mm, $P_{i}$ is total annual precipitation estimated at mean altitude of ith zone in $\mathrm{mm}, A_{i}$ is the area covered by ith zone, and $A$ is the total glacier surface area $\left(\sum A_{i}=A\right)$.

\section{Ablation}

\section{Meltwater production}

Meltwater produced on the glacier surface makes its way through the body of the glacier to the stream at the snout of

Table 1. Details of altitude zones and mean hypsometric altitudes ( see Fig. $4 a$ and $b$ )

\begin{tabular}{cccccc}
\hline Zone & Altitude range & $\begin{array}{c}\text { Area } \\
\left(A_{i}\right)\end{array}$ & Cumul. area & $\begin{array}{c}\text { Mean hyps. } \\
\text { altitude }\end{array}$ & $\begin{array}{c}\mathcal{N G A}^{*} \\
\left(A_{\mathrm{N} i}\right)\end{array}$ \\
& $\mathrm{m}$ & $\mathrm{km}^{2}$ & $\mathrm{~km}^{2}$ & $\mathrm{~m}$ & $\mathrm{~km}^{2}$ \\
\hline 1 & $<4000$ & 15.8 & 15.8 & 3790 & - \\
2 & $4000-4500$ & 82.2 & 98 & 4260 & 48.6 \\
3 & $4500-5000$ & 111.5 & 209.5 & 4770 & 85.6 \\
4 & $5000-5500$ & 290.1 & 499.6 & 5330 & 156.3 \\
5 & $5500-6000$ & 311.9 & 811.5 & 5740 & 49.3 \\
6 & $>6000$ & 175.6 & 987.1 & 6380 & - \\
\hline
\end{tabular}

* Non-glacierized area contributing to accumulation by avalanches. 
Table 2. Details of estimated annual accumulation values $(\mathrm{mm})$ at mean hypsometric altitudes of various altitude zones

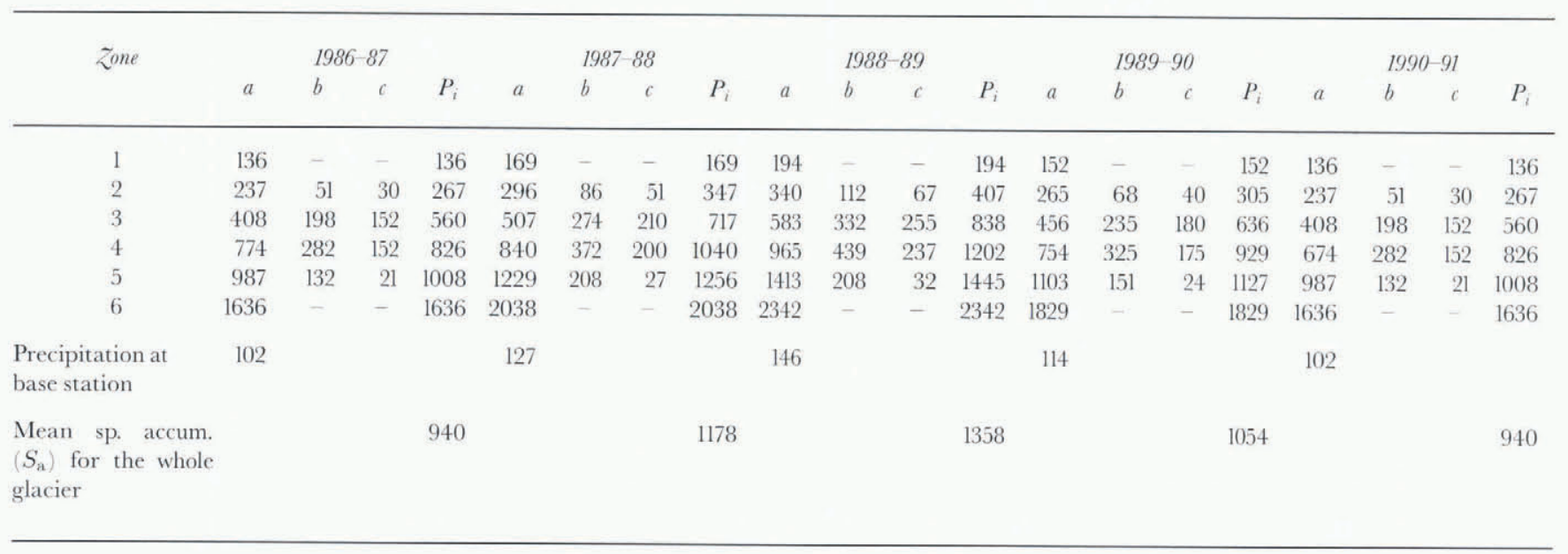

Notes: $a$ is precipitation due to normal snowfall on the glacier surface.

$b$ is precipitation in avalanche catchment areas of non-glacierized regions calculated using Equation (1) and subtracting residual of $0.15 \mathrm{~m}$.

$c$ is contribution by avalanches from non-glacierized regions weighted by their areas to the respective zones. $\left(c=b A_{\mathrm{N} i} / A_{i}\right.$.) (Values of $A_{i}$ and $A_{\mathrm{N} i}$ are given in Table 1.)

$P_{i}=a+c$.

$S_{\mathrm{a}}=\left(\sum P_{i} A_{i}\right) / \sum A_{i}$

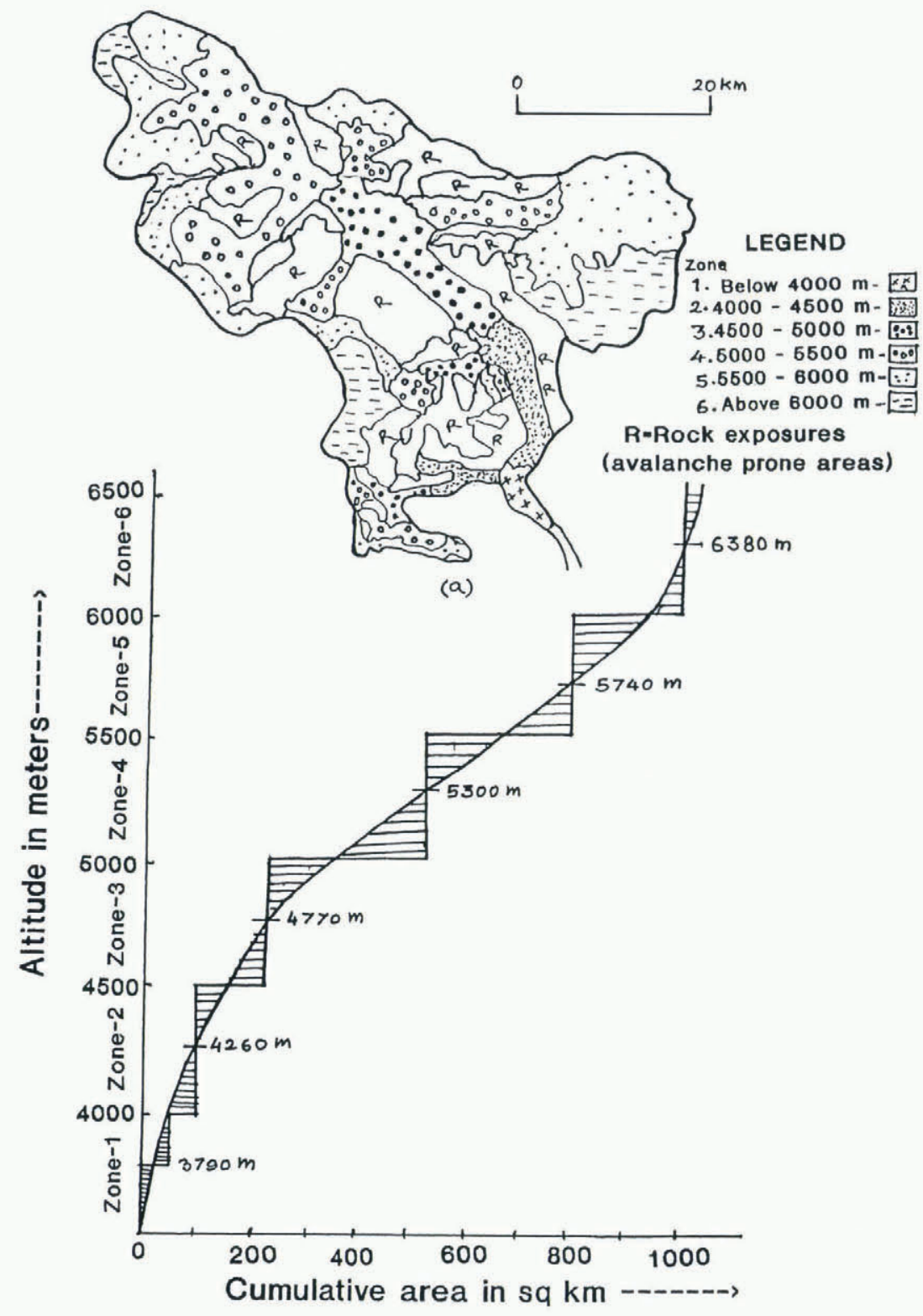

Fig. 4. Details of altitude zones and mean hypsometric altitudes. 

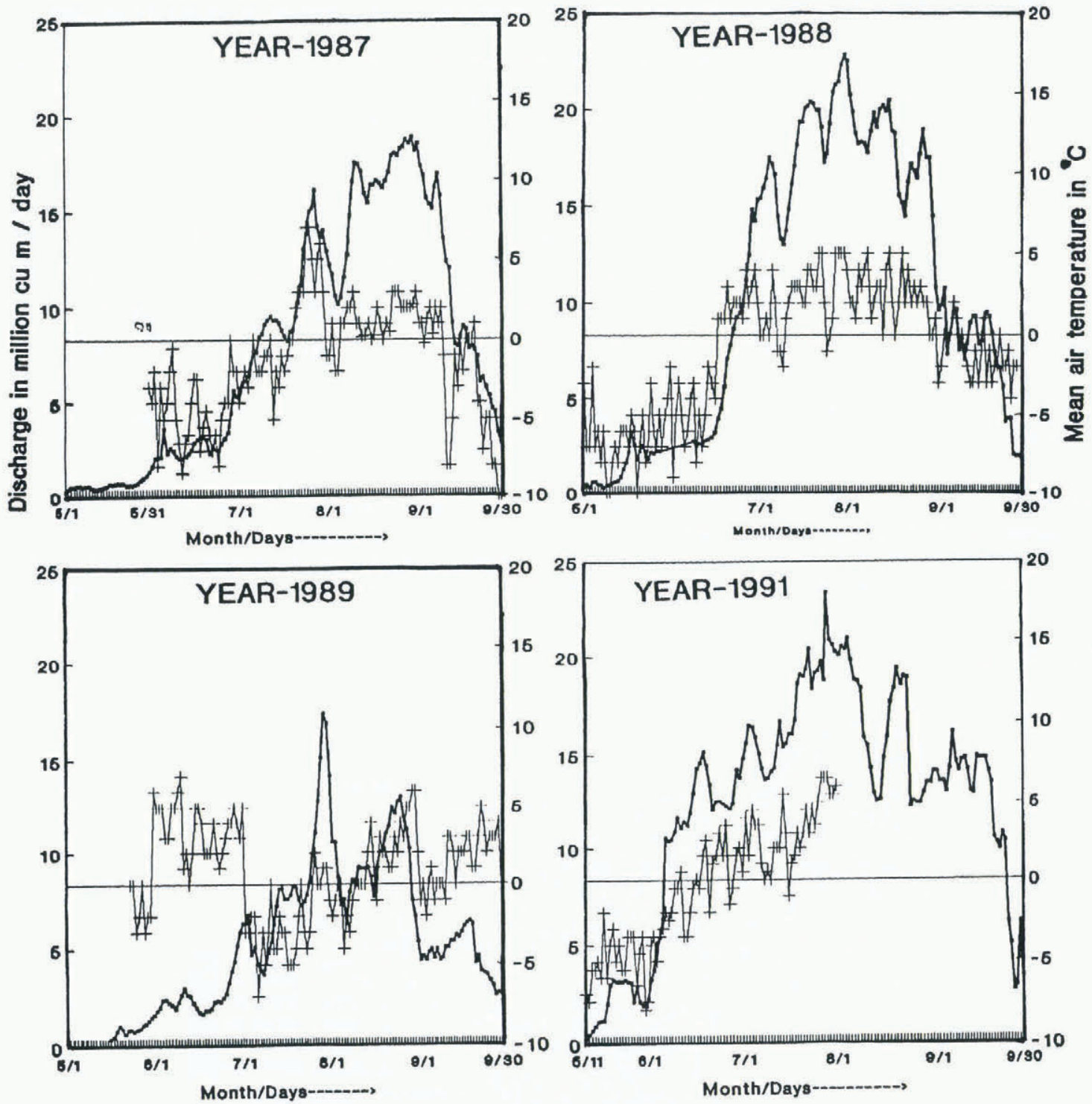

Fig. 5. Variation of daily discharge and mean air temperature at station A, Nubra river valley (discharge -- - , air temperature-+--).

the glacier. Assuming that changes in the groundwater storage are insignificant over the computational periods, the measurement of discharge in a proglacial stream should give a reasonably good estimate of the total meltwater production on the glacier. The discharge of the Nubra river was measured continuously during the summers of 1987, 1988, 1989 and 1991. Figure 5 gives the temporal variation of daily runoff and air temperature during the ablation season. The data show variations in daily runoff values ranging from $2.6 \times 10^{5} \mathrm{~m}^{3} \mathrm{~d}^{-1}$ at the start of the ablation season (first week of May) to about $2.3 \times 10^{7} \mathrm{~m}^{3} \mathrm{~d}^{-1}$ at the peak of the ablation season (August to early September). Figure 6 gives the relation between average monthly discharge and mean monthly air temperature. The discharge during the 1990 summer was estimated from this relationship because of non-availability of data.

\section{Evaporation losses}

The temperature data recorded at station A (4800 ma.s.l.) were used to estimate evaporation losses for the glacier. Mean annual air temperatures recorded at station $\mathrm{A}$ are given in Table 3. Evaporation losses on the snow surface are assumed to be negligible and hence are ignored. Due to surficial melting, the snow and glacier surface is assumed to resemble a lake surface. Yearly evaporation losses over an exposed snow and glacier surface are estimated by an empirical expression suggested by the U.S. Geological Survey for a lake surface (Mutreja, 1986).

$$
E_{\mathrm{s}}=4.57 T_{\mathrm{a}}+43.3
$$

where $E_{\mathrm{s}}$ is evaporation in $\mathrm{cm} \mathrm{a}^{-1}$ and $T_{\mathrm{a}}$ is mean annual air temperature in ${ }^{\circ} \mathrm{C}$.

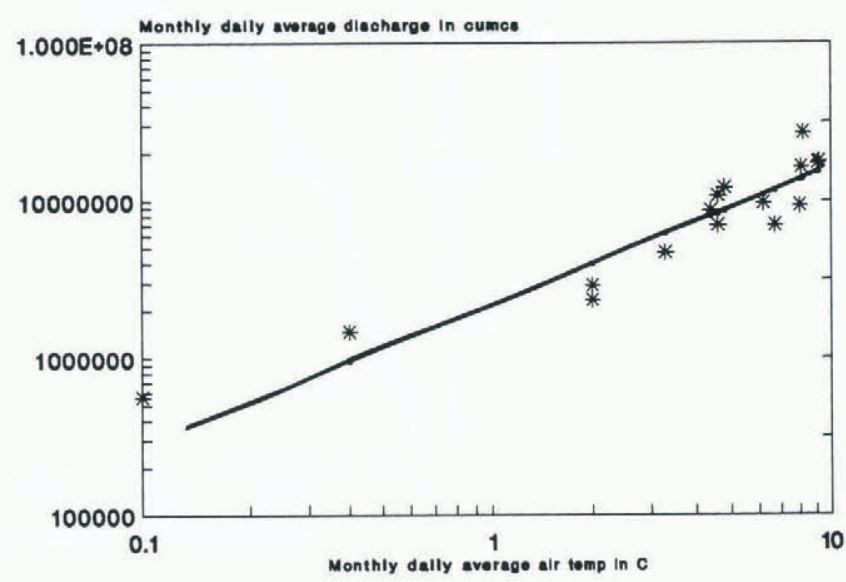

Fig. 6. Relationship between monthly average daily discharge and air temperature recorded at station A (4800 $m$ a.s.l.). 
Table 3. Mass-balance data of Siachen Glacier, 1986-87 to 1990-91

Year

$\begin{array}{ccccc}\text { Mean sp. } & \text { Mean sp. } & \text { Mean anmual Evaporation } & \text { Mean } \\ \begin{array}{c}\text { accumulation } \\ \left(S_{\mathrm{a}}\right)\end{array} & \begin{array}{c}\text { runoff } \\ (R)\end{array} & \begin{array}{c}\text { air temp. at } \\ \text { station } A\end{array} & \left(E_{\mathrm{s}}\right) & \left(S_{\mathrm{c}}\right) \\ \mathrm{mm} & \mathrm{mm} & \mathrm{C} & \mathrm{mm} & \mathrm{mm}\end{array}$

$\begin{array}{rrrrrr}1986-87 & 940 & 1255 & -5.7 & 173 & -488 \\ 1987-88 & 1178 & 1488 & -3.9 & 255 & -565 \\ 1988-89 & 1358 & 814 & -5.4 & 186 & 358 \\ 1989-90 & 1054 & 1598^{*} & -4 & 250 & -794 \\ 1990-91 & 940 & 1778 & -4.1 & 246 & -1084\end{array}$

* Estimated value.

\section{Net mass balance}

Mean specific mass-balance values of Siachen Glacier during the five hydrological years $1986-87$ to $1990-91$ are computed from:

$$
S_{\mathrm{c}}=S_{\mathrm{a}}-\left(R+E_{\mathrm{s}}\right)
$$

where $S_{\mathrm{c}}$ is mean specific mass balance, $S_{\mathrm{a}}$ is mean specific accumulation, $R$ is mean specific runoff, and $E_{\mathrm{s}}$ is mean yearly evaporation loss.

$S_{\mathrm{c}}$ values calculated by Equation (4) are given in Table 3.

It is seen from these data that except in the year 1988-89, the mass-balance values of Siachen Glacier were negative. The year 1990-91 appears to have recorded the lowest value of mass balance $(-1084 \mathrm{~mm})$, which may be attributed to comparatively low accumulation and high ablation. Figure 7 shows the variation of snowfall recorded during the ablation months. It is seen from these data that during the ablation season of 1990 91, the month of May which marks the beginning of the ablation season being the exception, June and July experienced no snowfall, and August and September recorded below normal snowfall amounts. The temperature data given in Table 4 show that abnormally high temperatures (about $5^{\circ} \mathrm{C}$ higher than the normal values) prevailed during June, which led to extensive ablation of the exposed glacier surface.

The year 1988-89 registered a positive mass balance $(+358 \mathrm{~mm})$. Besides comparatively high accumulation recorded in the winter of this year, during the ablation season there were significant snowfall events, with snowfall

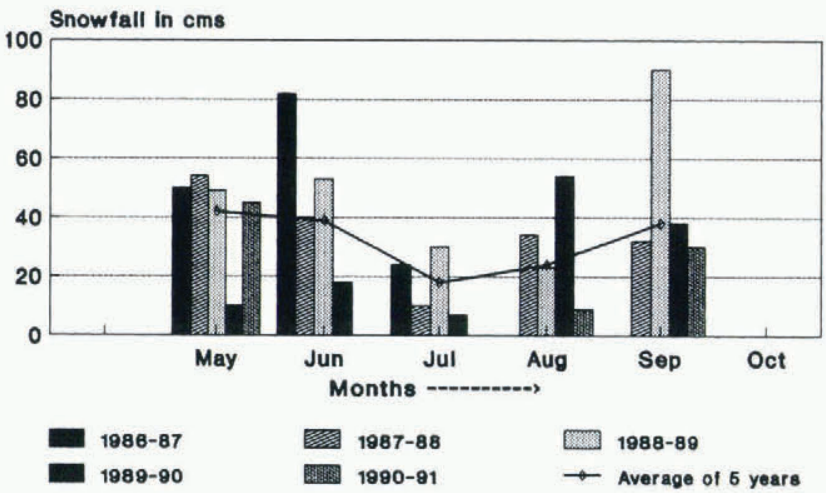

Fig. 7. Variation of snowfall (in $\mathrm{cm}$ snow depth) during ablation months at station A.
Table 4. Mean monthly air temperatures $\left({ }^{\circ} \mathrm{C}\right)$ at station $A$ during ablation periods in different years

\begin{tabular}{|c|c|c|c|c|c|c|}
\hline Month & $1986-87$ & $1987-88$ & $1988 \quad 89$ & $1989-90$ & $1990-91$ & Mean \\
\hline May & -2.7 & 0.4 & -1.6 & 1.9 & -0.9 & 0.6 \\
\hline June & 2.6 & 4.4 & 2 & 6.4 & 10.2 & 5.1 \\
\hline July & 6.3 & 9.1 & 6.7 & 6.7 & 6.9 & 7.7 \\
\hline August & 8.7 & 8.1 & 8 & 8 & 8.2 & 8.2 \\
\hline September & 4.2 & 4.6 & 3.3 & 3.3 & 5.8 & 4.4 \\
\hline
\end{tabular}

amounts well above normal values, and air temperatures $1-3{ }^{\circ} \mathrm{C}$ below normal values (Table 4 ). These factors were mainly responsible for substantially reduced ablation rates and positive mass balance.

\section{ERROR ANALYSIS OF RESULTS}

The main source of error in the glaciological method of determining mass balance is an error in measurement due to tilting and sinking of stakes in the glacier over a period of time. This may introduce a standard error of about $10 \%$ in annual mass-balance estimates (Tangborn and others, 1975). In the hydrological method, due to errors in manual recording of snow-meteorological data, and significant spatial and altitudinal variation in precipitation in mountainous areas, errors are likely to occur in the estimation of accumulation. To obtain more reliable accumulation estimates for Siachen Glacier, in this study, instead of using precipitation data from a single index station located near the centre of the glacier (Tangborn and others, 1975), data from five stations located at different altitudes were used and a relationship between altitude and precipitation was established. Observed and computed values of precipitation show good correlation $\left(R^{2}=0.89\right)$. The standard error estimated in this approach is about $19 \%$. The contribution by avalanches from non-glacierized areas surrounding the glacier has also been included to improve the accuracy of accumulation estimates. The reliability of the river discharge data cannot be ascertained, due to the non-availability of data measured by the salt-dilution method for comparison. However, the inherent standard error in the area-velocity method of discharge measurement is 10-15\% (Mutreja, 1986) and it is assumed those values are applicable in this study.

Evaporation measurements in the study region are few and far between. Data collected at Skardu on the banks of the Shyok river ( $2700 \mathrm{~m}$ a.s.l.) show that evaporation in valleys which are climatically arid in summer averages about $10 \mathrm{~mm} \mathrm{~d}^{-1}$ (Goudie and others, 1984). No data are available from higher altitudes where glaciers are located. For calculating the mass balance of Siachen Glacier, evaporation losses were estimated indirectly by using an empirical relationship between mean air temperature and evaporation (Mutreja, 1986). It is not possible to estimate standard error in these measurements, due to the lack of data collected by any other method, but an error of about $15-20 \%$ is assumed.

Considering the errors associated with accumulation, discharge and evaporation estimates, it is believed that net annual-balance estimates will also have the same standard error of about $15-20 \%$. 


\section{CONGLUSIONS}

The hydrological method, although not as accurate as the stratigraphic or geodetic method, can be used effectively to study mass balance of long glaciers like Siachen in the rugged and difficult terrain of the Karakoram Himalaya. The mass-balance computations for Siachen Glacier show that in every year except one (1988-89), negative massbalance values have been recorded since 1986 . This finding is consistent with observations that indicate that Siachen Glacier has been receding during the past 5 years, in conformity with the current trend of general retreat of all Himalayan glaciers (Raina and others, 1977; Kulkarni, 1992). Higher mean air temperatures and a fairly continuous trend of negative values of mass balance indicate a period of warmer climate and excessive runoff and ablation during the study period. In the absence of any other scientific data, and particularly mass-balance data, by any method on any glacier in this region, the results of this study can be accepted with an error of about $15-20 \%$.

\section{ACKNOWLEDGEMENTS}

The author is grateful to the Directorate of Military Intelligence, Army Headquarters, New Delhi, for granting security clearance and permission to publish the results of this study in the form of this paper. The encouragement received from Commandant, College of Military Engineering, Pune, Commander, Faculty of Civil Engineering and Head of Department of Survey, Brig. V.N. Nerikar is gratefully acknowledged. Thanks are also due to D. S. Thakur, R. C. Thakur and H. S. Thakur for their help during fieldwork.

\section{REFERENCES}

Bagchi, A. K. 1982. Orographic variation of precipitation in a high-rise Himalayan basin. International Association of Hydrological Sciences Publication 138 Symposium at Exeter 1982 - Hydrological Aspects of Alpine and High Mountain Areas), $3-9$.

Bhutiyani, M. R. 1992. The avalanche problems in Nubra and Shyok valleys in Karakoram Himalaya. 7. Inst. Mil. Eng. India, 3 3), 3-5.

Ferguson, R. I. 1984. Sediment load of the Hunza river. In Miller, K. J., ed. The International Karakoram Project, Proceedings of the International Conference.
Vol. 2. Cambridge, Cambridge University Press, 581-598.

Goudie, A. S. and 10 others. 1984. The geomorphology of the Hunza Valley, Karakoram mountains, Pakistan. In Miller, K. J., ed. The International Karakorum Project. Proceedings of the International Conference. Vol. 2. Cambridge, etc., Cambridge University Press, $359-410$.

Higuchi, K., Y. Ageta, T. Yasunari and J. Inoue. 1982. Characteristics of precipitation during the monsoon season in high-mountain areas of the Nepal Himalaya. International Association of Hydrological Sciences Publication 138 (Symposium at Exeter 1982 - Hydrological Aspects of Alpine and High Mountain Areas), 2130.

Kulkarni, A.V. 1992. Mass balance of Himalayan glaciers using AAR and ELA methods. J. Glaciol., 38 (128), 101-104.

Meier, M.F. 1973. Hydraulics and hydrology of glaciers. International Association of Hydrological Sciences Publication 107 (Symposium at Banff 1972 The Role of Snow and lce in Hydrology), Vol. 1, 353-370.

Mutreja, K. N. 1986. Applied hydrology. New Delhi, Tata-McGraw-Hill Publishing Co. Ltd.

Östling, M. and R. LeB. Hooke. 1986. Water storage in Storglaciären, Kebnekaise, Sweden. Geogr. Ann., 68A (4), 279-290.

Østrem, G. 1964. A method of measuring water discharge in turbulent streams. Geogr. Bull. 21, 21-43.

Ostrem, G. and A. D. Stanley. 1969. Glacier and mass balance measurements; $a$ manual for field and office work: a guide for personnel with limited backgrounds in glaciology. Ottawa, Ont., Department of the Environment, Inland Waters Branch. (IWB Reprint Series 66.)

Raina, V. K., M. K. Kaul and S. Singh. 1977. Mass-balance studies of Gara Glacier. 7. Glaciol., $18(80), 415-423$.

Rangachary, N. and B. K. Bandyopadhyay. 1987. An analysis of the synoptic weather pattern associated with extensive avalanching in western Himalaya. International Association of Hydrological Sciences Publication 162 (Symposium at Davos 1986 - Avalanche Formation, Movement and Effects, $311-316$

Röthlisberger, H. and H. Lang. 1987. Glacial hydrology. In Gurnell, A. M. and M.J. Clark, eds. Glacio-fluvial sediment transfer: an alpine perspective. Chichester, etc., John Wiley and Sons, 207-284.

Schaerer, P. A. 1975. Relation between the mass of avalanches and characteristics of terrain at Rogers Pass, B.C., Canada. International Association of Hydrological Sciences Publication 104 (Symposium at Moscow 1971 Snow and Ice), $378-380$.

Singh, P. 1994. Study on snow distribution with altitude in the Chenab basin. In International Symposium on Snow and Related Manifestations, 26-28 September 1994, Manali, India. Proceedings. Manali, India, Snow and Avalanche Study Establishment, 618 627.

Tangborn, W. V., R. M. Krimmel and M. F. Meier. 1975. A comparison of glacier mass balance by glaciological, hydrological and mapping methods, South Cascade Glacier, Washington. International Association of Hydrological Sciences Publication 104 (Symposium at Moscow 1971 - Snow and Ice), $185-196$.

Vohra, C. P. 1981. Himalayan glaciers. In Lal, J. S. and A. D. Moddie, eds. The Himalaya: the aspects of change. Oxford, Oxford University Press, 138-151. 